\title{
Alkylation of Phenol with Olefins in the Presence of Sulphuric Acid
}

\author{
Manoranjan Saha*, M. Kabir Hossain, M. Ashaduzzaman, Shams Tania Afroza Islam, \\ Mirza Galib and Nashid Sharif \\ Department of Applied Chemistry and Chemical Technology, Univesity of Dhaka, \\ Dhaka-1000, Bangladesh.
}

\begin{abstract}
Alkylphenols have been synthesised in high yield by the alkylation of phenol with olefins $\left(\mathrm{C}_{6}-\mathrm{C}_{8}\right)$ in the presence of sulphuric acid. The effects of the variation of temperature, molar ratio of phenol to olefin, time of reaction, concentraction and amount of sulphuric acid have also been studied on the reactions.
\end{abstract}

Keywords: Alkylation, Phenol, Sulphuric Acid

\section{Introduction}

To protect synthetic fuels, lubricating oils and polymeric materials against thermal degradation due to heat, light, air, oxygen, ozone etc, use of antioxidant has become increasingly important. Alkylphenols and their derivatives are excellent antioxidants and stabilizers in such media (Lebedev, 1984; Ravikovich, 1964; Shreve and Brink 1977). They are also pour-point depressants for transmission fluid, corrosion inhibitors, plasticizers for polymeric materials (Egorov et al. 1978; Lebedev, 1984; Nelicova et al. 1974; Randell and Pickles,1978). Alkylphenols with an alkyl group of 5-8 carbon atoms are strong bactericides and with an alkyl group of 9-12 carbon atoms are valuable intermediates for nonionic detergents (Dritriev et al. 1961). Some of their derivatives are strong herbicides, insecticides, plant growth regulators, antiseptics etc (Akhmedov et al.1978; Belov and Isagulyants, 1964; Klarmann, 1938; Lebedev, 1984; Mills, 1940; Mills, 1941; Newman et al.1947; Okazaki et al. 1951). Derivatives of alkylphenols can also be used in paints and varnishes, dye, perfume and soap industries (Kheifits and Podberezina,1968; Topchiev et al. 1962).

Alkylation of phenols with olefins (Karim et al. 2005; Saha et al. 1996; Tesvetkov et al. 1970; Topchiev et al.1964;Topchiev et al. 1964), alcohols (Saha and Badruzzaman,

*Corresponding author, E-mail: manoranjansaha2005@yahoo.com 
1990; Saha et al. 2000; Saha and Roy,1992) and alkylhalides (Akhmedov et al.1978; Alieva and Akhmedov, 1983; Turaeva et al. 1976) has been investigated in the presence of protic and aprotic acids by severals authors. But the reactions have not been investigated in the presence of sulphuric acid as catalyst.

In the present work, attempt has been made to investigate the reaction of phenol with olefins $\left(\mathrm{C}_{6}-\mathrm{C}_{8}\right)$ in the presence of sulphuric acid as catalyst.

\section{Materials and Methods}

Reactions were carried out in a three necked round bottomed flask fitted with a stirrer, a condenser, a thermometer and a dropping funnel. Phenol and sulphuric acid were charged into the flask and heated to the desired temperature and olefins were introduced dropwise to the mixture for a certain period of time (time of addition) with constant stirring. After the addition of the olefins, the reaction mixture was stirred for an extended period of time (time of stirring) at the same temperature. The reaction mass was then cooled to room temperature, dissolved in ether, neutralized with saturated $\mathrm{NaHCO}_{3}$ solution and washed with distilled water several times and then subjected to distillation. Unreacted reactants and solvent were distilled off at atmospheric pressure. Products thus obtained were distilled and characterized by IR- and ${ }^{1} \mathrm{H}$ NMR- spectroscopic methods.

\section{Results and Discussion}

\section{A. Reaction of phenol with hexene-1 and cyclohexene}

Results of the reaction of phenol with hexene- 1 in the presence of sulphuric acid are recorded in Table I. The reaction gave sec.hexylphenol. sec.- Hexylphenol were obtained in $65.8 \%$ yield under the following conditions: temperature $=140^{\circ} \mathrm{C}$, molar ratio of phenol to hexene-1 = 6:1, amount of $94 \%$ sulphuric acid $=8 \%$ by wt. of phenol, time of addition $=2 \mathrm{~h}$ and time of stirring $=2 \mathrm{~h}$.

In the IR- spectrum of sec.-hexylphenol, band at $740 \mathrm{~cm}^{-1}$ was the characteristics of 1 , 2- disubstituted benzene ring and band at $815 \mathrm{~cm}^{-1}$ showed the presence of 1,4 - disubstituted benzene ring. The presence of $-\mathrm{OH}$ group was indicated by band at near 3200$3600 \mathrm{~cm}^{-1}$ in the product. The signals of the protons in the ${ }^{1} \mathrm{H}$ NMR-spectrum of sec.hexylphenol have been recorded in Table II.

Table I. Alkylation of phenol with hexene-1 in the presence of $94 \%$ sulphuric acid (temperature = $140^{\circ} \mathrm{C}$, time of addition $=2 \mathrm{~h}$, time of stirring $=2 \mathrm{~h}$, amount of sulphuric acid $=8 \% \mathrm{by} \mathrm{wt}$. of phenol)

\begin{tabular}{l|c|c}
\hline Expt. No. & Molar ratio of phenol to hexene-1 & \% yield of sec.-hexylphenol \\
\hline 1 & $4: 1$ & 30.1 \\
2 & $5: 1$ & 48.2 \\
3 & $6: 1$ & 65.8 \\
\hline
\end{tabular}


The reaction of phenol with cyclohexene in the presence of sulphuric acid was investigated over the temperature range of 50 - $140^{\circ} \mathrm{C}$ (Table III). Molar ratio of phenol to cyclohexene was varied from $4: 1$ to $8: 1$, reaction time from 3 to $4 \mathrm{~h}$ and the amount of catalyst from 3 to $7 \%$ by wt. of phenol. The reaction gave cyclohexylphenol. The yield of phenol to cyclohexene $=6: 1$, amount of $94 \%$ sulphuric acid $=7 \%$ by wt. of phenol, time of addition $=2 \mathrm{~h}$ and time of stirring $=1 \mathrm{~h}$.

In the IR- spectrum of cyclohexylphenol, band at $750 \mathrm{~cm}^{-1}$ was the characteristic of 1 , 2- disubstituted benzene ring and band at $815 \mathrm{~cm}^{-1}$ showed the presence of 1 , 4- disub

Table II. Signals of the protons in the ${ }^{1} \mathrm{H}$ NMR-spectrum of sec.-hexylphenol

\begin{tabular}{l|c}
\hline Observed signals of the protons & Chemical shift in ppm \\
\hline Four protons on the aromatic ring & $6.36-7.43$ \\
One proton on the -OH group & 5.46 \\
All the protons of the sec.-hexyl group except one on & \\
the $\alpha$-position relative to the aromatic ring & $0.56-2.73$ \\
One proton on the $\alpha$-position & $3.00-3.83$ \\
\hline
\end{tabular}

cyclohexylphenols increased with the increase in temperature (Expt. no. 1 and 2; 4 and 7) molar ratio of phenol to cyclohexene (Expt. no. 3-5; 2 and 6), amount of catalyst (Expt. no. 2 and 3; 5 and 6). Thus the best yield (80\%) of cyclohexylphenol was obtained under the following reaction conditions: temperature $=140^{\circ} \mathrm{C}$, molar ratio of stituted benzene ring. The presence of $-\mathrm{OH}$ group was indicated by band near at 3150 $3600 \mathrm{~cm}^{-1}$ in the product.

\section{B. Reaction of phenol with heptene-1 and cycloheptene}

sec.- Heptylphenol was obtained in $73.8 \%$ yield by the alkylation of phenol with hep

Table III. Alkylation of phenol with cyclohexene in the presence of $94 \%$ sulphuric acid

\begin{tabular}{l|c|c|c|c}
\hline \multirow{2}{*}{ Expt. No. } & \multicolumn{3}{|c|}{ Reaction conditions (Time of addition, 2h; time of stirring,1h) } & \% yield of cyclo- \\
\cline { 2 - 4 } & $\begin{array}{c}\text { Temp., } \\
{ }^{0} \mathrm{C}\end{array}$ & $\begin{array}{c}\text { Molar ratio of phenol } \\
\text { to cyclohexene }\end{array}$ & $\begin{array}{c}\text { Amount of sulphuric acid, } \\
\text { \% by wt. of phenol }\end{array}$ & hexylphenol \\
\hline 1 & 50 & $4: 1$ & 3 & 40.8 \\
2 & 100 & $4: 1$ & 3 & 61.4 \\
3 & 100 & $4: 1$ & 7 & 73.6 \\
4 & 100 & $6: 1$ & 7 & 75.5 \\
5 & 100 & $8: 1$ & 7 & 78.3 \\
6 & 100 & $8: 1$ & 3 & 65.9 \\
7 & 140 & $6: 1$ & 7 & 80.00 \\
\hline
\end{tabular}


tene- 1 in the presence of sulphuric acid under the following conditions: temperature $=140^{\circ} \mathrm{C}$, molar ratio of phenol to heptene- 1 $=6: 1$, amount of $94 \%$ sulphuric acid $=8 \%$ by wt. of phenol, time of addition $=2 \mathrm{~h}$ and time of stirring $=2 \mathrm{~h}$.

The IR-spectrum of sec.-heptylphenol showed the absorption band at $750 \mathrm{~cm}^{-1}$ for the 1,2 - disubstituted benzene ring and band at $820 \mathrm{~cm}^{-1}$ for the 1, 4- disubstituted benzene ring. Band at $3400 \mathrm{~cm}^{-1}$ accounted for the presence of $-\mathrm{OH}$ group in the product.

The signals of the protons in the ${ }^{1} \mathrm{H}$ NMRspectrum of sec.-heptylphenol have been represented in Table IV.

Sulphuric acid catalysed reaction of phenol and cycloheptene gave cycloheptylphenol in 88.6\% yield under the following conditions: temperature $=140^{\circ} \mathrm{C}$, molar ratio of phenol to cycloheptene $=6: 1$, amount of catalyst $=$ $8 \%$ by wt. of phenol, concentration of sulphuric acid $=94 \%$, time of addition $=2 \mathrm{~h}$ and time of stirring $=2 \mathrm{~h}$.

In the IR- spectrum of these products, the presence of $-\mathrm{OH}$ group was indicated by band at $3400 \mathrm{~cm}^{-1}$. Band at $750 \mathrm{~cm}^{-1}$ indicat- ed the presence of 1,2 - disubstituted ben zene ring and band near $810 \mathrm{~cm}^{-1}$ accounted for 1, 4- disubstituted benzene ring in the product.

Table V showed the values of chemical shift in ppm of the protons in the ${ }^{1} \mathrm{H}$ NMR- spectrum of cycloheptylphenol.

\section{Reaction of phenol with octene-1}

Results of the reaction of phenol with octene- 1 in the presence of $94 \%$ sulphuric acid have been shown in Table VI. The reaction gave sec.-octylphenol in $94.7 \%$ yield under the following conditions: temperature $140^{\circ} \mathrm{C}$, molar ratio of phenol to octene- $1=$ $10: 1$, amount $94 \%$ sulphuric acid $=8 \%$ by wt. of phenol, time of addition $=2 \mathrm{~h}$, time of stirring $=2 \mathrm{~h}$. The presence of $-\mathrm{OH}$ group was indicated by band at $3350 \mathrm{~cm}^{-1}$ in the IRspectrum of sec.-octylphenol. Band at 750 $\mathrm{cm}^{-1}$ accounted for the presence of 1,2 - disubstituted benzene ring and at $810 \mathrm{~cm}^{-1}$ for the 1, 4- disubstituted benzene ring in the product.

Chemical shifts in ppm of the protons in the ${ }^{1} \mathrm{H}$ NMR- spectrum of sec.-octylphenol have been recorded in Table VII.

Table IV. Signals of the protons in the ${ }^{1} \mathrm{H}$ NMR-spectrum of sec.-heptylphenol

\begin{tabular}{l|c}
\hline Observed signals of the protons & Chemical shift in ppm \\
\hline Four protons on the aromatic ring & $6.43-7.33$ \\
One proton on the -OH group & 5.7 \\
All the protons of heptyl group except one on the & \\
$\alpha$-position relative to the aromatic ring & $0.63-2.00$ \\
One proton on the $\alpha$-position & $3.78-4.0$ \\
\hline
\end{tabular}


Table V. Signals of the protons in the ${ }^{1} \mathbf{H}$ NMR- spectrum of cycloheptylphenol

\begin{tabular}{l|c}
\hline Observed signals of the protons & Chemical shift in ppm \\
\hline $\begin{array}{l}\text { Four protons on the aromatic ring } \\
\text { One proton on the -OH group }\end{array}$ & $6.33-7.33$ \\
All the protons on the cycloheptane ring except one on & \\
the $\alpha$-position relative to the aromatic ring & 1.63 \\
One proton on the $\alpha$-position & $2.17-3.27$ \\
\hline
\end{tabular}

Table VI. Alkylation of phenol with octene-1 in the presence of $94 \%$ sulphuric acid (temperature $=140^{\circ} \mathrm{C}$, time of addition $=2 \mathrm{~h}$, time of stirring $=2 \mathrm{~h}$, amount of sulphuric acid $=8 \% \mathrm{by}$ wt. of phenol)

\begin{tabular}{l|c|c}
\hline Expt. No. & Molar ratio of phenol to octene- 1 & \% yield of sec.-octylphenol \\
\hline 1 & $6: 1$ & 81.4 \\
2 & $8: 1$ & 85.8 \\
3 & $10: 1$ & 94.7 \\
\hline
\end{tabular}

Table VII. Signals of the protons in the ${ }^{1} \mathrm{H}$ NMR- spectrum of sec.-octylphenol

\begin{tabular}{l|c}
\hline Observed signals of the protons & Chemical shift in ppm \\
\hline Four protons on the aromatic ring & $6.33-7.17$ \\
One proton on the -OH group & $5.07-5.83$ \\
All the protons of sec.-octyl group except one on the & \\
$\alpha$-position relative to the aromatic ring & $0.6-1.83$ \\
One proton on the $\alpha$-position & 3.33 \\
\hline
\end{tabular}

\section{References}

Akhmedov, K.N. Turaeva, M.K. Abdurasulaeva, A.R. (1978) Alkylation of 2-and 4chlorophenols. Dokl. Akal. Nauk. Uzle. USSR. 10: 47-48.

Alieva, M.K. Akhmedov, K.N. (1983) Alkylation of 2- and 4- chlorophenols by alkyl halides in the presence of small amount of catalysts. Zh. Org. Khim. 19 (10) : 2131-2134.

Belov, P.S. Isagulyants, V.I. (1964) Alkylation of $p$-cresol with cyclic alcohol in the presence of cation exchange resin KU-2. Zh. Prikl. Khim. 37 (11): 2505-2508.
Dritriev, S.A. Corner, K.D. Tsvtkov, O.N. (1961) Synthesis of detergents based on phenol derived from peat oils. Torfyanoya Prom. 32(6): 24-27.

Egorov, V.D. Prokazov, A.I. Rumyantsev, A.G. Podlesnaya, L.A. Jarakanov, G.A. Zhelobad'Ko, V.F. Melnikova, L.D. Grigoryan, V. G. (1978) Experience of producing the additive APK. Neftepererab Neftekhim. Moscow. 12: 31-32.

Karim, M.Z. Ismail, M. Kamruzzaman, M. Saha, M. (2005) Alkylation of o-cresol with cyclopentene in the presence of $p$-toluen 
sulphonic acid. Bangladesh J. Sci. Ind. Res. 40 (3-4): 331-336.

Kheifits, L.A. Podberezina, A.S. (1968) Synthesis of perfume from alkylphenols and some principles of the alkylation of phenols by branched olefins, Tr. Veses. Sin Natur. Dushistykh-Veshehestv. 8: 115-142.

Klarmann, E. (1938) Monoalkylchlorophenols. US Patent. 2139550.

Lebedev, N.N. (1984) Chemistry and Technology of Basic Organic and Petrochemical Synthesis. Mir publishers, Moscow 1\&2. p. 638.

Mills, L.E. (1940) Alkylated Halo-phenols. US Patent. 2176010.

Mills, L.E. (1941) Tertiary Halo-phenols. US Patent. 2221807.

Nelicova, E.M. Spivok, R.E. Bakhshi-Zade, A.A. (1974) Alkylation of phenol by $\mathrm{C}_{9}-\mathrm{C}_{12}$ fraction in the presence of the catalyst KU-2. Azerb. Neft Khoz. 54 (10): 41-44.

Newman, M. S. Fones, W. Renoll, M. (1947) New compounds as plant-growth regulators. J. Am. Chem. Soc. 69 (3): 718-723.

Okazaki, K. Kato, H. Mathui, K. (1951) Relation between bactericidal and insecticidal activities. J. Pharm. Soc. Japan. 71: 495.

Randell, D.R. Pickles, W. (1978) Phosphorylated secondary butylated phenol/phenol ether mixture. US Patent. 4096209.

Ravikovich, A.M. (1964) Antioxidants for minerals and synthetic lubricating oils. Chemistry and technology of fuels and oils. 11: 68-71.

Saha, M. Badruzzaman, M. (1990) Comparative studies on the reaction of cresols with alcohols in the presence of benzenesulphonic acid. Bangladesh J. Sci. Res. 8(2): 213-215.
Saha, M. Basak, P.K. Saha, D. Alam, M.Z. (2000) Alkylation of $m$-cresol with $n$-alcohols in the presence of sulphuric acid. Bangladesh J. Sci. Res. 18 (1): 95-102.

Saha, M. Mosihuzzaman, M. Saha, S. (1996) Alkylation of $p$-cresol with cyclohexene in the presence of benzenesulphonic acid. Indian J. Chem. Technol. Vol. 3: 292-294.

Saha, M. Roy, R.K. (1992) Alkylation of mcresol with cyclohexanol in the presence of sulphuric acid. Bangladesh J. Sci. Ind. Res. 27(3-4): 23-29.

Shreve, R.N. Brink, J.A. (1977) Chemical Process Industries. 4th Edition. p. 814.

Tesvetkov, O.N. Korenev, R.D. Dmitrev, S.A. Kazakov, E.I. Botyaikina, I.N. Zimina, K.I. and Kotova, G.G. (1970) Composition of the alkylphenols obtained by alkylation of phenol by unbranched olefins. Neftpererab. 72: 12254.

Topchiev, A.V. Tumerman, B.M. Solovena, G.A. (1964) Alkylation of phenol by $n$-olefins with catalysts containing borontrifluride. $T r$. Inst. Prom. 51: 19-24.

Topchiev, A.V. Zavgorodnii, S.A. Kryuchnova, V.G. (1964) Alkylation with olefins. Elsevier Publishing Company, AmsterdamLondon-New York. p. 324.

Turaeva, M. K. Akhmedov, N. Abdurasuleva, A.R. (1976) Alkylation of phenols and their ethers in the presence of small amount of catalysts. Alkylation of 3- chlorophenol and 3- chloroanisol with alkyl halides in the presence of ironsalts. Deposited Doc. VINITI 3010-3076.

Received : September 30, 2007;

Accepted : September 18, 2008. 